\title{
Overview of an Emerging Coronavirus Infection, COVID-19: Current Status of Vaccine Development and Therapeutics
}

\author{
Md. Sohel Rana1, Md. Maruf Hasan², Md. Eshak Enan², Fatema-Tuz-Zohora',2, \\ A. T. M. Zafrul Azam ${ }^{1}$ \\ ${ }^{1}$ Department of Pharmacy, Faculty of Pharmacy, University of Dhaka, Dhaka, Bangladesh \\ ${ }^{2}$ Department of Pharmacy, Primeasia University, 9 Banani C/A, Dhaka, Bangladesh \\ Email: fatema.zohora41@gmail.com
}

How to cite this paper: Rana, Md.S., Hasan, Md.M., Enan, Md.E., Zohora, F.-T. and Azam, A.T.M.Z. (2021) Overview of an Emerging Coronavirus Infection, COVID-19: Current Status of Vaccine Development and Therapeutics. Pharmacology \& Pharmacy, $12,25-41$

https://doi.org/10.4236/pp.2021.121003

Received: September 21, 2020

Accepted: January 26, 2021

Published: January 29, 2021

Copyright $\odot 2021$ by author(s) and Scientific Research Publishing Inc. This work is licensed under the Creative Commons Attribution International License (CC BY 4.0).

http://creativecommons.org/licenses/by/4.0/

(c) (i) Open Access

\begin{abstract}
Coronavirus infectious disease 2019 (COVID-19) first reported in Wuhan, China, causes serious respiratory illnesses such as lung failure and pneumonia. Severe Acute Respiratory Syndrome Coronavirus 2 (SARS-CoV-2) the pathogenic agent of COVID-19 has been confirmed as a novel coronavirus. WHO announced COVID-19 a global pandemic and now the whole world is eagerly waiting for vaccines and therapeutic treatment to get rid of this unstoppable coronavirus. As COVID-19 infection, a global threat creates unwanted human casualties and serious economic loss. To stop the ongoing uncontrolled situation researchers are racing to develop prevention and treatment strategies. Vaccines of different countries are in clinical and preclinical trials and the repurposed-drugs are providing to find out a positive result against COVID-19. The report is an analysis of published information focusing on treatment options including vaccination, drug-therapy, cytokines, therapeutic antibodies. Most of the vaccine's development strategies and drugs target the surface structural spike glycoprotein or S-protein, the major inducer of pathogenic responses. Here, it is reviewed the features of SARS-CoV-2 and the global current status of therapeutic, and vaccine development for the prevention and effective treatment of COVID-19.
\end{abstract}

\section{Keywords}

COVID-19, Epidemiology, Therapeutic, Vaccine, S Protein

\section{Background of the Study}

The first coronavirus infection was experienced globally by Severe Acute Respi- 
ratory Syndrome (SARS) in 2002-2003 and again by Middle East Respiratory Syndrome (MERS) in 2011 [1]. The pathogenic agents i.e., SARS-CoV and MERS-CoV in both cases respectively were characterized as beta coronavirus with a zoonotic origin. Again, at the end of the year of 2019, another new coronavirus (Severe Acute Respiratory Syndrome Coronavirus-2) outbroke globally. This SARS-CoV-2 causes respiratory-related illness was first reported in Wuhan, Hubei, China. Now this disease is officially called "the Corona Virus Disease 2019; COVID-19". The genome of newly identified SARS-CoV-2 is fully sequenced [2]. The first confirmed case of SARS-CoV-2 infection was reported on 17 November 2019, who was a 55-year-old citizen in the Hubei province [3]. Health authorities in China reported to the World Health Organization (WHO) on 31 December 2019, a cluster of viral pneumonia cases of unknown cause responsible for respiratory infection in Wuhan, Hubei, and an investigation was started in early January 2020 [4]. As 7818 cases confirmed globally by Coronavirus Disease (COVID-19) the WHO declared the outbreak a Public Health Emergency of International Concern (PHEIC) on 30 January [5]. On March $12^{\text {th }}$, 2020, the WHO declared the epidemic of COVID-19 as a pandemic [6]. The outbreak of COVID-19 that began in Wuhan in China in December last year has now turned into a pandemic. At present, more than 200 countries have confirmed cases of the virus. Most of us have not experienced anything similar to the current situation. The virus has struck with unprecedented scale and ferocity. Educational institutions, shops, restaurants, recreational facilities, and many others are closed for a few months or more. Our lives have almost come to a halt. All these are done for a very good reason-to retard the spread of the virus. The COVID-19 crisis has played out in ways that have not been anticipated from the prevailing nature of governance in different countries. Governments and health care systems almost in all affected countries caught short-handed. For the prevention and control of COVID-19, many nations and communities around the world are trying their best to implementation of appropriate strategies. Nothing certain treatment and prevention strategies like antiviral drugs or vaccines are available for human and animal coronavirus infections [7]. During Ebola, Zika, and Nipah various vaccines, drug options, and immunotherapeutic have been explored [8]. The safety, efficacy, and potency of previously explored drugs, vaccines and other treatment options in the above-mentioned diseases can play a vital role to discover valuable modalities for tackling the emerging COVID-19 [9] [10]. Until the development of vaccines or discovery of any treatment option we cannot halt the new, deadly, and highly infectious coronavirus disease, COVID-19, which has brought much of the world to a locked-down situation and standstill [11].

\section{Epidemiology}

First now the global threat SARS-CoV-2, a newly discovered coronavirus closely related to bat coronaviruses, pangolin coronaviruses in the phylogenetic tree 
[12]. SARS-CoV and MERS-CoV are very much similar to SARS-CoV-2 according to the genomic sequence. Since its first reported case in late 2019, the infection has spread to other regions in China and other countries, and the transmission rate, the mortality rate, and the clinical manifestation slowly emerged. It will take time, we completely characterize the transmission pattern, pathogenesis, symptoms, origin, and immune response of the SARS-CoV-2 virus [2]. As of July 12, 2020, a total of 13,028,182 confirmed COVID-19 positive cases reported at least in 213 countries and territories around the world with an approximately $4.38 \%$ of fatality rate $(571,080 / 13,028,182)$ [13]. The mortality rate $4.38 \%$ of SARS-CoV-2 [13] is lower than that of SARS-CoV (10\%) [14] or MERS-CoV (37.1\%) [15] but the infection rate and the number are about 10 times higher than others. Transmission of SARS CoV-2 from mild, moderate, severely symptomatic, or asymptomatic persons to persons is reported in many published reports [16]. Similar to the case for SARS-CoV and MERS-CoV are similar in origin [15], as $96 \%$ genome sequence is identical to bat coronaviruses like bat CoV, BatCoV RaTG13 so the bat is considered the probable origin of SARS-CoV-2 [15]. As with SARS and MERS coronavirus, SARS-CoV-2 is predicted to commonly pass through intermediate hosts, such as civets or camels, before leaping to humans though scientific consensus is that COVID-19 has a natural origin [17] [18].

\section{General Clinical Features of COVID-19}

A wide range of clinical manifestations is seen in SARS-CoV-2-infected patients for example-mild, moderately severe to rapidly progressive state with particular organ dysfunction. The generalized common symptoms were fever $(77.4 \%$ 98.6\%), fatigue $(38.1 \%-69.6 \%)$, cough $(59.4 \%-81.8 \%)$, sputum production $(28.2 \%-56.5 \%)$, myalgia $(11.1 \%-34.8 \%)$, dyspnea $(3.2 \%-55.0 \%)$, and headache $(6.5 \%-33.9 \%)$ [19] [20] [21]. Less common symptoms like chest pain, diarrhea, Sore throat, conjunctival congestion, rhinorrhea, hemoptysis, nausea, and vomiting are seen in COVID-19 patients [19] [20] [21]. One study reported that 55 out of 140 confirmed COVID-19 patients had gastrointestinal symptoms [22], but in Wang's study $10.1 \%$ of patients are showed with gastrointestinal discomfort at the onset [21]. It's not necessary to have a fever at the onset of COVID-19 infection but fever may develop after hospitalization and some patients did not have a fever [23]. Similar clinical symptoms such as fever, cough, myalgia, and dyspnea were shown in SARS-CoV, MERS-CoV, and SARS-CoV-2 infections [24]. COVID-19 patients in comparison with SARS and MERS have less gastrointestinal involvement (about one-third) [25]. SARS-CoV-2 attacks different people in various ways. Mild to moderate illness were developed in most COVID-19 infected people and most of the time they recovered without hospitalization [26].

\section{Diagnosis of COVID-19}

Before COVID-19 positive patients were suffering from $35.3 \%$ - 82.1\% lympho- 
penia, 5.0\% - 36.2\% thrombocytopenia, and 9.1\% - 33.7\% leukopenia [19] [20] [21]. Chen et al. found elevated C-reactive protein (CRP), serum ferritin, erythrocyte sedimentation rate (ESR), and interleukin-6 (IL6) prominently [20]. Other studies also reported increased levels of Alanine aminotransferase (ALT), D-dimer, aspartate aminotransferase (AST), lactate dehydrogenase (LDH), prolonged prothrombin time (PT), and creatine kinase (CK) [26]. COVID-19 is detected earlier by some radiological examinations including chest computed tomography (CT) scan and chest X-ray (CXR) [27]. Followings are the most common chest CT scans patterns of COVID-19 i.e. multiple Ground-Glass Opacity (GGO) lesions (56.4\%), and shadowing of the bilateral patch (51.8\%), and the other pattern types consist of shadowing of local a patch $(28.1 \%)$, and interstitial abnormalities (4.4\%). A chest CT scan shows more prominent radiologic findings on severe cases such as more bilateral patchy shadowing (82\%), more multiple GGO lesions (60\%), and more local patchy shadowing (55.1\%) than non-severe cases. No abnormalities were significantly identified in CXR or chest CT of $2.9 \%$ of severe cases and $17.9 \%$ of non-severe cases [19] [20] [21]. SARS-CoV-2 infection was confirmed as a positive result of real-time reverse-transcriptase polymerase-chain-reaction (RT-PCR) or highthroughput sequencing assay for determining COVID-19 in a laboratory manner [28].

\section{SARS-CoV-2 Molecular Biology}

Define Coronaviruses (CoVs) are single-stranded and enveloped positive-sense 5'-3' RNA virus belonging to the Coronaviridae family, which originally found in various species of birds, bats, snakes, and other mammals [29]. 229E, HKU1, NL63, and OC43 were the previously known coronaviruses strains that infected humans in various ways [30]. The latest SARS CoV-2 is also an enveloped, single-stranded positive-sense viruses $((+)$ ssRNA virus). Coronaviruses subfamily Coronavirinae is divided into four genera such as alpha, beta, gamma, and delta coronaviruses. Among these four classes of coronavirus Severe Acute Respiratory Syndrome coronavirus (SARS-CoV), Middle East Respiratory Syndrome coronavirus (MERS-CoV), and Severe Acute Respiratory Syndrome coronavirus-2 (SARS-CoV-2) belong to beta-coronavirus. As like SARS-CoV and MERS-CoV, novel SARS-CoV-2 primarily and prominently attacks the lower respiratory system to cause viral pneumonia [31]. The SARS CoV-2 is a spherical shape of about $125 \mathrm{~nm}$ size particle with club-shaped spikes. The Spike protein looking like the Sun's corona (crown) carrying moiety that gives the spiky appearance to the virions. The latest cryo-electron microscopy along with tomographic techniques has been used to demonstrate the full structure of SARS-CoV-2 in various molecular biology research laboratories [32]. This relatively large RNA viral genome has approximately $30(26$ - 32) kb pairs. The virus has structural S-spike protein (spiky glycoprotein about $150 \mathrm{kD}$ ), M-membrane protein (a transmembrane glycoprotein, type III), N-nucleocapsid protein (within the phos- 
pholipid bilayer), and E-envelope protein, and some nonstructural proteins, which are encoded by the various genetic loci on the RNA of the viruses. The genomic RNA and the nucleocapsid protein develop nucleocapsid which lies at the center of the virion (Figure 1) [33].

The viral RNA genome of beta coronavirus encodes several structural and non-structural proteins, among the structural proteins spike (S) protein acts as a major inducer and binding site that binds with host cell and provide pathological responses. Structural surface $\mathrm{S}$ protein binds with the host cell surface receptor protein named Angiotensin-Converting Enzyme-2 (ACE2) and through this SARS-CoV-2 invades into host cell alike SARS-CoV invasion mechanism [34]. Several nonstructural proteins (nsp-16) encode by the viral genome including RNA-dependent RNA polymerase (RdRp), papain-like protease (PLpro), coronavirus main protease (3CLpro) [35]. After the successful entrance of the virus into the host cells, the genome is released into the host cell cytoplasm as a single-stranded non-fragmented positive-sense RNA. As early as possible in a suitable environment, this viral genomic RNA uses the protein translation machine of the host cell and is translated into viral polyproteins. These polyproteins are then cleaved by viral proteinases PLpro and 3CLpro to produce effector proteins [36]. A full-length negative-strand RNA is synthesized by RNA-dependent RNA polymerase (RdRp). Many copies of viral genomic RNA are made by using newly synthesized RNA as a template with the help of RdRp [37]. Infection initiates after interaction between viral S protein and ACE2 on the host cell surface and this binding interaction is very important for drug targets [38] [39]. The binding affinity of S protein of SARS-CoV-2 to ACE2 is about $10-20$ times higher than $S$ protein of SARS-CoV and this is revealed after Cryo-Electron Microscopy structure analysis (Figure 2) [37].

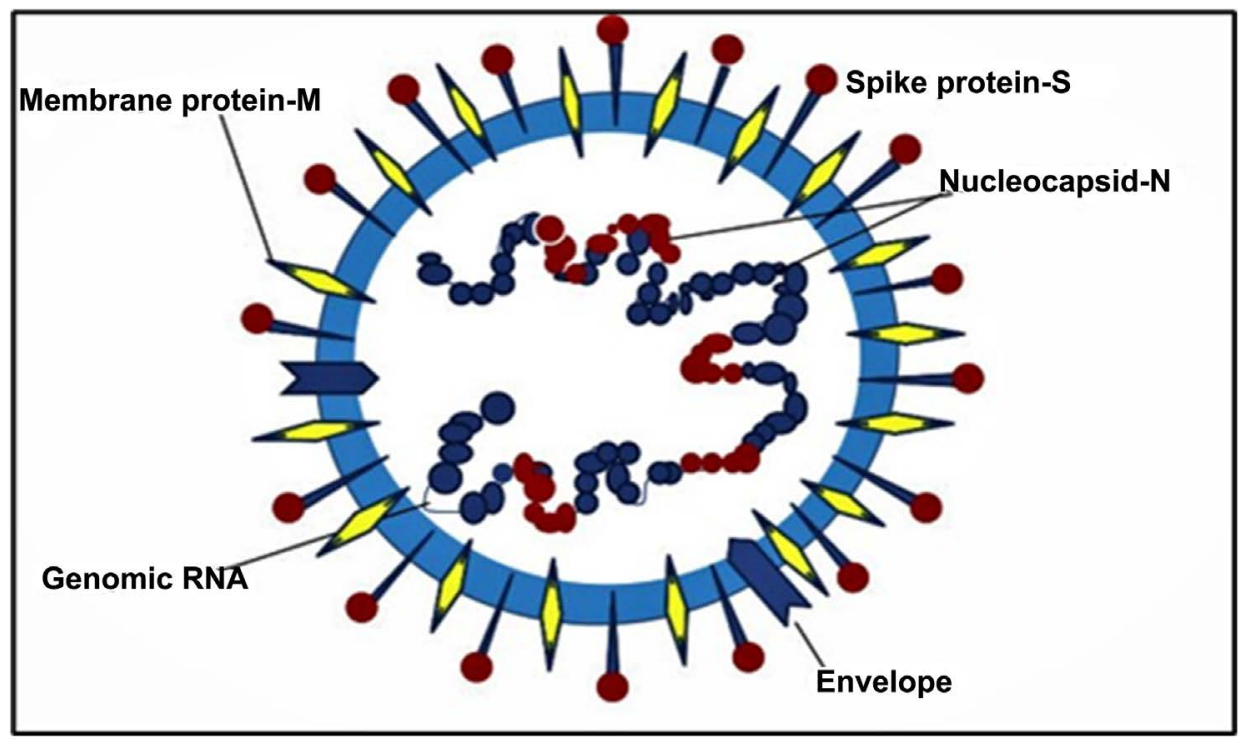

Figure 1. SARS-CoV-2 diagrammatic representation with genetic materials and structural proteins [34]. 


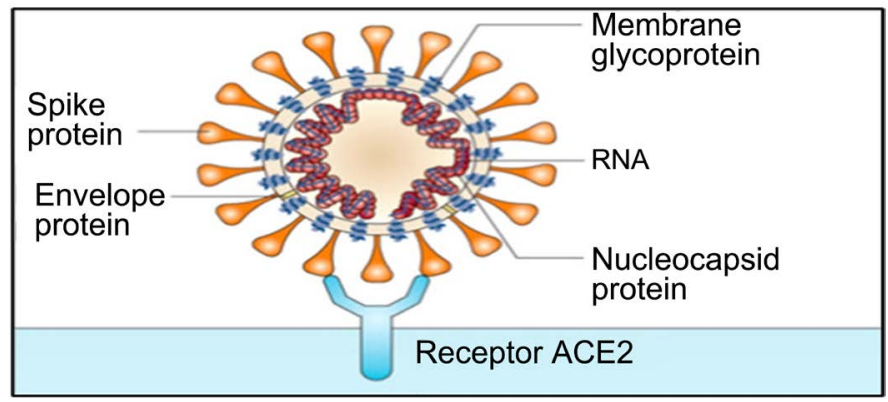

Figure 2. Illustrated representation of SARS-CoV-2 binding with ACE2 on the host cell surface [38]

\section{Factors of Virus (SARS-CoV-2) Transmission}

The SARS CoV-2 is transmitted from person to person by some environmental, physical, and biological means including air, inanimate surfaces, hands, temperature, water and sewage, humidity, wind speed, food, and insects [40] [41] [42].

1) Droplet transmission densely occurs when a person is coughing or sneezing with respiratory symptoms and other persons are in close contact (within $1 \mathrm{~m}$ ) and is therefore at risk of having his/her mucosae (mouth and nose) or conjunctiva (eyes) exposed to potentially infective respiratory droplets. Respiratory infections can be transmitted through droplets of different sizes: when the droplet particles are $>5-10 \mu \mathrm{m}$ in diameter they are referred to as respiratory droplets, and when they are $<5 \mu \mathrm{m}$ in diameter, they are referred to as droplet nuclei. According to current evidence, the COVID-19 virus is primarily transmitted between people through respiratory droplets and contact routes [40]. Transmission may also occur through fomites in the immediate environment around the infected person [41].

2) Airborne transmission occurs when microbes (SARS CoV-2) in droplet nuclei particles and particle size less than $5 \mu \mathrm{m}$ in diameter can easily float in the air for a long duration of time and transmit from one area to another area [41]. The airborne transmission was not significant in an analysis of 75,465 COVID-19 cases in China [42].

3) SARS-CoV-2 may also transmit through feces because COVID-19 may lead to intestinal infection and viruses may be present in feces and this transmission is proved with evidence in some studies. In the meantime, a single study has found the COVID-19 virus by microbe culture from an infected person's stool specimen [43].

4) Recent study report confirmed the presence of the SARS-CoV-2 virus in water and sewage. Even in the low prevalence of the virus, it is present in the wastewater which indicates the survival capacity of the SARS-CoV-2 virus in the sewage [44] [45].

\section{Treatment Strategies for Corona Virus Disease (COVID-19)}

\subsection{Vaccines}

The whole world is eagerly waiting for vaccines as it the only effective strategy 
for preventing and stopping pandemic causing infectious disease [23] [26]. Vaccines are more cost-effective and convenient than treatment and through which morbidity and mortality can easily be reduced without long-lasting adverse effects [16]. Following vaccine development strategies are considering by the scientists to find an effective and potent vaccine to fight against the SARS-CoV-2 virus [46] [47].

1) Recombinant Subunit Vaccine: Generally, subunit vaccines boost the immune system and act against the specific pathogenic virus without introducing that virus into the host body and it is highly safe with fewer side effects [16]. Clover Biopharmaceuticals is running a recombinant subunit vaccine pre-clinical trial for COVID-19 by targeting the trimeric S protein (S-Trimer) of the SARSCoV-2. The University of Queensland is using a transformative technology called "molecular clamp "for developing subunit vaccines and they also implement GSK's adjuvant system in their effective vaccine development process [46].

2) DNA-Based Vaccines: A DNA-based patent candidate WO2005081716 discloses its compositions and development methods. This vaccine candidate enhances antigen-specific CD8+ T cell-mediated immune responses against antigens of the SARS coronavirus. Antigenic peptide or polypeptide of SARS $\mathrm{CoV}-2$ is bound with endoplasmic reticulum chaperone polypeptide (e.g., calreticulin) which is encoded by chimeric nucleic acids and that induces a T-cell mediated immune response [38]. Inovio Pharmaceuticals is running with a pre-clinical trial for DNA vaccine (INO-4800) against COVID-19 in collaboration with Beijing Advaccine Biotechnology. INO-4800 induces activation of $\mathrm{T}$ cells by DNA plasmids which are responsible for the S-protein of SARS-CoV-2 [16].

3) Live Vector Vaccines: Live vector vaccines express a non-pathogenic antigen(s) and they induce very strong immunogenicity [48]. University of Oxford is developing ChAdOx1 viral vector vaccine which is very potential and effective vector against human coronavirus. The Jenner Institute of University of Oxford's ChAdOx1 nCoV-19 vaccine developed in a partnership between Italian pharmaceutical manufacturer Advent Srl. Live vector attenuated adenovirus was responsible for expressing spike (S) protein of SARS-CoV-2 induced anti-pathogenic effects by [49].

4) Protein-Based Vaccines: GlaxoSmithKline (GSK) applies for patent WO2010063685 vaccine which is capable of providing a protective immune response against SARS. The vaccine is an adjuvant mixture of $S$ protein immunogen along with an oil-in-water (o/w) emulsion. Anti-SARS-CoV IgG2a or IgG2b antibody induced immune responses by this engineered adjuvant combination vaccine found in a clinical trial and animal models showed neutralizing antibody-induced immune responses [38]. The recombinant protein in the form of vaccine was represented in the immune system to induce antigenicity found in the convalescent SARS CoV-2 patient's serum, to bind specific protein with host ACE2 cell surface receptor, to facilitate antibody-dependent viral entry or refractory human Raji B cells, to reduce protection against viral infection in a 
pre-clinical animal model [38] [46].

5) Virus-like Particle Vaccines: In the year 2015, Novavax addressed a vaccine patent application WO2015042373 targeting MERS CoV. Minimum one trimer of an S protein and MERS-CoV nanoparticle formed this immunogenic composition. Recombinant nanoparticle technology with adjuvant Matrix-M used for the development of a virus-like particle vaccine against COVID-19 by targeting the S protein of SARS-CoV-2 [7] [46].

6) mRNA-Based Vaccines: Prophylactic mRNA vaccines can potentially reduce natural infection by boosting immune response as well as implicating multiple mRNAs into a single vaccine formulation. Modern submits patent application WO2017070626 mRNA vaccine which mainly composed of S, S1, or S2 proteins encoded by mRNAs of SARS-CoV, MERS-CoV, and SARS-CoV-2 virus. A cationic lipid nanoparticle delivery system is used for mRNA-based vaccines. A pre-clinical study showed that animal models vaccinated with full-length $S$ protein generating mRNA induced higher neutralizing antibody titers in comparison with S protein S2 subunit encoding mRNA [7] [38].

7) Inactive Candidate Vaccines: Inactivated viruses are cultured and produced which don't have the disease-causing capacity. Under proper control and protocol pathogens (viruses) are killed to reduce virulence so that the vaccine's virus materials cannot induce any infections. In this case heat or formaldehyde is used as a tool for vaccine inactivation [7] [46]. According to the utilized methods for the inactivation of virus inactive vaccines are classified. Previous studies of the SARS vaccine may act as a reference as a potential successive source of the COVID-19 vaccine candidate [9] [50].

Previously experienced SARS and MERS outbreak knowledge help our scientists to identify and discover a potential development pathway of vaccines. Mechanisms of vaccine development mainly came from SARS-CoV and MERS-CoV vaccine studies summarized in Table 1.

\subsection{Convalescent Plasma (CP) Therapy}

For the prevention and treatment of infectious diseases, many countries allow convalescent plasma (CP) immunotherapy. During SARS, MERS, and H1N1 infection $\mathrm{CP}$ has shown effective immune response and boosted immunity against these infectious diseases [52] [53]. Neutralizing antibody containing plasma is taken from a donor who has recently recovered from this special type of infection. This extracted plasma is then administered to infected patients. Ongoing clinical reported that severe or critically ill COVID-19 patients who received CP therapy showed significant improvement in their health conditions [54]. Furthermore, other researches are conducting to identify specific characterized antibodies found in the recovered patient's plasma. Also trying to develop monoclonal antibodies for the treatment of COCVID-19, China and other countries approved convalescent plasma therapy specifically antibody therapy [53]. 
Table 1. 24 selected antigens and vaccine platforms that have been tested (clinical trial) for SARS-CoV-2 [51].

\begin{tabular}{|c|c|c|c|c|c|}
\hline Platform & Type of candidate vaccine & Developer & $\begin{array}{l}\text { Coronavirus } \\
\text { target }\end{array}$ & $\begin{array}{l}\text { Current stage of clinical } \\
\text { evaluation/regulatory status } \\
\text { Coronavirus candidate }\end{array}$ & $\begin{array}{l}\text { Same platform for } \\
\text { non-Coronavirus } \\
\text { candidates }\end{array}$ \\
\hline Inactivated & Inactivated + alum & Sinovac & SARS-CoV-2 & $\begin{array}{l}\text { Phase } 3 \\
\text { NCT04456595 } \\
\text { Phase } 1 / 2 \\
\text { NCT04383574 NCT04352608 }\end{array}$ & SARS \\
\hline $\begin{array}{l}\text { Non-Replicatin } \\
\text { g Viral Vector }\end{array}$ & ChAdOx1-S & $\begin{array}{l}\text { University of } \\
\text { Oxford/AstraZeneca }\end{array}$ & SARS-CoV-2 & $\begin{array}{l}\text { Phase } 3 \\
\text { ISRCTN89951424 Phase2b/3 } \\
2020-001228-32 \\
\text { Phase } 1 / 2 \\
\text { PACTR202006922165132 } \\
2020-001072-15\end{array}$ & $\begin{array}{l}\text { MERS, influenza, } \\
\text { TB, Chikungunya, } \\
\text { Zika, MenB, plague }\end{array}$ \\
\hline $\begin{array}{l}\text { Non-Replicatin } \\
\text { g Viral Vector }\end{array}$ & Adenovirus Type 5 Vector & $\begin{array}{l}\text { CanSino Biological } \\
\text { Inc./Beijing Institute of } \\
\text { Biotechnology }\end{array}$ & SARS-CoV-2 & $\begin{array}{l}\text { Phase } 2 \text { ChiCTR2000031781 } \\
\text { Phase } 1 \text { ChiCTR2000030906 }\end{array}$ & Ebola \\
\hline Protein Subunit & $\begin{array}{l}\text { Adjuvanted recombinant } \\
\text { protein (RBDDimer) }\end{array}$ & $\begin{array}{l}\text { Anhui Zhifei Longcom } \\
\text { Biopharmaceutical/Institute of } \\
\text { Microbiology, Chinese } \\
\text { Academy of Sciences }\end{array}$ & SARS-CoV-2 & $\begin{array}{l}\text { Phase } 2 \text { NCT0 } 4466085 \text { Phase } \\
1 \text { NCT04445194 }\end{array}$ & MERS \\
\hline RNA & LNP encapsulated mRNA & Moderna/NIAID & SARS-CoV-2 & $\begin{array}{l}\text { Phase } 3 \text { (not yet recruiting) } \\
\text { NCT04470427 Phase } 2 \\
\text { NCT04405076 Phase } 1 \\
\text { NCT04283461 }\end{array}$ & multiple candidates \\
\hline DNA & $\begin{array}{l}\text { DNA plasmid vaccine with } \\
\text { electroporation }\end{array}$ & $\begin{array}{l}\text { Inovio Pharmaceuticals/ } \\
\text { International Vaccine Institute }\end{array}$ & SARS-CoV-2 & $\begin{array}{l}\text { Phase } 1 / 2 \text { NCT04447781 } \\
\text { NCT04336410 }\end{array}$ & multiple candidates \\
\hline DNA & $\begin{array}{l}\text { DNA plasmid vaccine }+ \\
\text { Adjuvant }\end{array}$ & $\begin{array}{l}\text { Osaka University/AnGes/ } \\
\text { Takara Bio }\end{array}$ & SARS-CoV-2 & Phase $1 / 2$ NCT04463472 & \\
\hline DNA & DNA Vaccine (GX-19) & Genexine Consortium & SARS-CoV-2 & Phase 1/2 NCT04445389 & \\
\hline DNA & DNA plasmid vaccine & Cadila Healthcare Limited & SARS-CoV-2 & $\begin{array}{l}\text { Phase } 1 / 2 \\
\text { CTRI/2020/07/026352 (not } \\
\text { yet recruiting) }\end{array}$ & \\
\hline Inactivated & Inactivated & $\begin{array}{l}\text { Wuhan Institute of Biological } \\
\text { Products/Sinopharm }\end{array}$ & SARS-CoV-2 & $\begin{array}{l}\text { Phase } 1 / 2 \\
\text { ChiCTR2000031809 }\end{array}$ & \\
\hline Inactivated & Inactivated & $\begin{array}{l}\text { Beijing Institute of Biological } \\
\text { Products/Sinopharm }\end{array}$ & SARS-CoV-2 & $\begin{array}{l}\text { Phase } 1 / 2 \\
\text { ChiCTR2000032459 }\end{array}$ & \\
\hline Inactivated & Whole-Virion Inactivated & Bharat Biotech & SARS-CoV-2 & $\begin{array}{l}\text { Phase } 1 / 2 \\
\text { CTRI/2020/07/026300 }\end{array}$ & \\
\hline Protein Subunit & $\begin{array}{l}\text { Full length recombinant } \\
\text { SARS-CoV-2 glycoprotein } \\
\text { nanoparticle vaccine } \\
\text { adjuvanted with Matrix M }\end{array}$ & Novavax & SARS-CoV2 & Phase $1 / 2$ NCT04368988 & $\begin{array}{l}\text { RSV; CCHF, HPV, } \\
\text { VZV, EBOV }\end{array}$ \\
\hline Protein Subunit & RBD-based & Kentucky Bioprocessing, Inc & SARS-CoV2 & Phase $1 / 2$ NCT04473690 & \\
\hline RNA & 3 LNP-mRNAs & $\begin{array}{l}\text { BioNTech/Fosun } \\
\text { Pharma/Pfizer }\end{array}$ & SARS-CoV2 & $\begin{array}{l}\text { Phase } 1 / 2 \\
2020-001038-36 \\
\text { NCT04368728 }\end{array}$ & \\
\hline Inactivated & Inactivated & $\begin{array}{l}\text { Institute of Medical Biology, } \\
\text { Chinese Academy of Medical } \\
\text { Sciences }\end{array}$ & SARS-CoV2 & $\begin{array}{l}\text { Phase } 1 \\
\text { NCT04412538 }\end{array}$ & \\
\hline
\end{tabular}




\section{Continued}

\begin{tabular}{|c|c|c|c|c|c|}
\hline $\begin{array}{l}\text { Non Replicatig } \\
\text { Viral Vector }\end{array}$ & Adeno-based & Gamaleya Research Institute & SARS-CoV-2 & $\begin{array}{l}\text { Phase } 1 \\
\text { NCT04436471 NCT0 } 4437875\end{array}$ & \\
\hline Protein Subunit & $\begin{array}{l}\text { Native like Trimeric } \\
\text { subunit Spike Protein } \\
\text { vaccine }\end{array}$ & $\begin{array}{l}\text { Clover Biopharmaceuticals } \\
\text { Inc./GSK/Dynavax }\end{array}$ & SARS-CoV-2 & $\begin{array}{l}\text { Phase } 1 \\
\text { NCT04405908 }\end{array}$ & $\begin{array}{l}\text { HIV, REV } \\
\text { Influenza }\end{array}$ \\
\hline Protein Subunit & $\begin{array}{l}\text { Recombinant spike protein } \\
\text { with Advax }{ }^{\text {sex }} \text { adjuvant }\end{array}$ & Vaxine Pty Ltd/Medytox & SARS-CoV-2 & $\begin{array}{l}\text { Phase } 1 \\
\text { NCT04453852 }\end{array}$ & \\
\hline Protein Subunit & $\begin{array}{l}\text { Molecular clamp stabilized } \\
\text { Spike protein with MF59 } \\
\text { adjuvant }\end{array}$ & $\begin{array}{l}\text { University of } \\
\text { Queensland/CSL/Seqirus }\end{array}$ & SARS-CoV-2 & $\begin{array}{l}\text { Phase } 1 \\
\text { ACTRN12620000674932p }\end{array}$ & $\begin{array}{l}\text { Nipah, influenza, } \\
\text { Ebola, Lassa }\end{array}$ \\
\hline RNA & LNP-nCoVsaRNA & Imperial College London & SARS-CoV-2 & $\begin{array}{l}\text { Phase } 1 \\
\text { ISRCTN17072692 }\end{array}$ & $\begin{array}{l}\text { EBOV; LASV, } \\
\text { MARV, Inf } \\
\text { (H7N9), RABV }\end{array}$ \\
\hline RNA & mRNA & Curevac & SARS-CoV-2 & $\begin{array}{l}\text { Phase } 1 \\
\text { NCT04449276 }\end{array}$ & $\begin{array}{l}\text { RABV, LASV, } \\
\text { YFV; MERS, InfA, } \\
\text { ZIKV, DENV, } \\
\text { NIPV }\end{array}$ \\
\hline RNA & mRNA & $\begin{array}{l}\text { People's Liberation Army } \\
\text { (PLA) Academy of Military } \\
\text { Sciences/Walvax Biotech. }\end{array}$ & SARS-CoV-2 & Phase 1 ChiCTR2000034112 & \\
\hline VLP & $\begin{array}{l}\text { Plant-derived VLP } \\
\text { adjuvanted with GSK or } \\
\text { Dynavax adjs. }\end{array}$ & Medicago Inc. & SARS-CoV-2 & Phase 1 NCT04450004 & $\begin{array}{l}\text { Flu, Rotavirus, } \\
\text { Norovirus, West } \\
\text { Nile virus, Cancer }\end{array}$ \\
\hline
\end{tabular}

\subsection{Drug Repurposing for COVID-19}

Previously used antiviral drugs can be used as an effective treatment for symptomatic and hospitalized patients, though the drugs are not yet confirmed as a treatment option, the approach of repurposing these old drugs is under investigation against this newer viral infection [52] [53]. WHO already announced the international clinical SOLIDARITY trial to overcome the challenge and stop the pandemic [54]. Following antiviral and adjunct drugs are used for the treatment of COVID-19 in the approach of a clinical trial:

- Lopinavir (LPV)-Ritonavir (RTV) combination (Kaletra): FDA-approved antiviral drug for HIV-1 treatment. Lopinavir acting as a protease inhibitor that inhibits virus particle maturation by stopping the replication step in HIV1, whereas ritonavir synergistically increases the activity of lopinavir. Ritonavir inhibits CYP3A enzymes that slow down the broken-down rate of lopinavir in the liver [55]. COVID-19 patients (mild and moderate) are treated with a combination of Lopinavir and ritonavir (NCT04252885) as a part of clinical trial [56]. In another a clinical trial reported that no significant benefits of the lopinavir-ritonavir combination were observed with severe COVID-19 patients (ChiCTR2000029308) [57].

- Favipiravir (Favilavir or Avigan): Fujifilm Toyama Chemical in Japan developed Favipiravir (FPV) which is an RNA-dependent RNA polymerase inhibitor. Favipiravir is proved as safe and effective in other viral infections 
such as Influenza, Ebola, Lassa. Some clinical trials conducted in Wuhan and Shenzhen have been shown that it is also useful against SARS-CoV-2 [58]. Patients who received Favipiravir demonstrated better therapeutic and immune response by facilitating viral clearance at a faster rate and also shown better chest imaging. The aforementioned results were considered promising that's why the National Medical Products Administration of China approved favipiravir as the first anti-COVID-19 drug in the country [59].

- Chloroquine/Hydroxychloroquine: Chloroquine is WHO enlisted essential medicines which is an inexpensive drug for the treatment of malaria. Chloroquine induces antiviral activities by increasing endosomal $\mathrm{pH}$ which inhibits replication of the viruses such as Ebola and Marburg. A more stable ana$\log$ of Chloroquine is Hydroxychloroquine which is considered more clinically and therapeutically safe as well as demonstrates anti-SARS-CoV-2 activity [56] [58]. (Uddin et al., 2020) mentioned a recent clinical trial that azithromycin in combination with hydroxychloroquine therapy has shown disappointing results in critically-ill COVID-19 hospitalized patients. Some experts thought that absence of zinc supplement could be one reason behind the limited success of this combination therapy during some clinical trials against SARS-CoV-2 and other RNA virus infections [53].

- Remdesivir (GS-5734): Remdesivir, a broad-spectrum nucleotide analog antiviral prodrug, acts against many RNA viruses. It has been proved effective against SARS-CoV, MERS-CoV, and SARS-CoV-2 in preclinical trials by inhibiting replication of the virus. A report of randomized, placebo-controlled, double-blind, multicenter clinical trial of remdesivir in 237 patients in Hubei, China, has just been published. In this published report, there were no statistically significant clinical benefits except reduction in time to symptomatic clinical improvement [60]. Another study reported that the first COVID-19 confirmed patient's condition in the USA was improved on the $8^{\text {th }}$ day after hospitalization after receiving remdesivir therapy for seven days without any noticeable adverse effects [26].

- Corticosteroids: Corticosteroids are immunomodulatory drugs used in the treatment of COVID-19 critically ill patients for prolonging their lives and this study is under observation [2] [7]. The corticosteroid molecules for example Prednisolone, Betamethasone, dexamethasone inhibit the expression of many inflammatory molecules that are encoded by some genes. Cardiovascular disease, bone fragility, bone density loss are the adverse effects of long-term use of corticosteroids [33]. A study showed a disappointing result that the mortality rate increased to influenza pneumonia patients when administered corticosteroids. In contrast, a retrospective study in China stated that patients who developed Acute Respiratory Disease Syndrome (ARDS) were found with decreased death rate. Various clinical trials are still ongoing [61].

- Ivermectin: Ivermectin is a broad-spectrum lipophilic macrolide anti-parasitic drug used against many invertebrates. Ivermectin shows antiparasitic activity 
by binding with glutamate-gated chloride ion channels, which causes depolarization of the cells. A multicenter clinical trial with 1400 patients showed that the death rate reduced from $21 \%$ to $7 \%$ when ivermectin was administered [61] [62]. A study conducting in India to compare ivermectin to standard of care and another ongoing study in Kentucky in combination with ivermectin and hydroxychloroquine which data gives some hope to fight against SARS-CoV-2 [62]. RNA of SARS-CoV-2 is reduced up to 5000-folds within 48 hours after administration of Ivermectin which is published in another clinical study [62].

\subsection{Non-Pharmacological Interventions}

Still, there are no vaccines or specific confirmed pharmacological interventions or therapy available to minimize or stop the rapidly transmitting of SARS-CoV-2 around the world [58]. We are on the very verge of vaccines discovery but until vaccines are marketed and available for all classes of people globally, we have to consider some effective non-pharmacological interventions (NPI) for COVID-19 treatment. Implementation of non-pharmacological interventions (NPI) such as early case identification and isolation, travel restrictions, vigilant contact tracing of potential secondary cases and bans, physical ("social") distancing, regular hand washing, stringent contact reductions, and improved hygiene [38]. Some approaches like non-necessary public spaces should be closed, services and facilities should be reduced, quality digital learning facilities for educational institutions should be encouraged, and self-isolation/work from or inside the home should be inspired. If these NPIs strategies are implemented as early as possible the deadly viral transmission could be minimized [53].

\section{Summary}

In this review report authors would like to provide an overview of published different information about the Corona Virus Infectious Disease 2019 (COVID-19) which is a global threat. Here molecular biology of the SARS-CoV-2 virus and prevention as well as treatment strategies of COVID-19 is described in brief. Zoonotic origin beta-coronavirus SARS-CoV-2 caused severe casualties in every sphere of human life globally. Now it is the prime concern to slow down the spread of the virus and reduce the rate and number of infections as early as possible by any means, in the meantime most effective and suitable prevention (vaccines) along with treatment options (therapeutics) is being searched and trialed continuously. Except for vaccine, some drugs and treatment options are found to be effective against this deadly virus COVID-19. However, the lack of clinical evidence may lead to an unpredictable clinical prognosis. The potential impact of biologics for the treatment of coronavirus infections is promising and includes a wide variety of options including bioengineered and vectored antibodies, cytokines, and nucleic acid-based therapies targeting virus gene expression as well as various types of vaccines. The development of therapeutics and vac- 
cines for the treatment of COVID-19 is towards a remarkable ending, there has been some significant progress in the research area from complete genome sequencing of SARS-CoV-2 to the endings of clinical trials with COVID-19 vaccines. Continued international efforts are required to solve the remaining unanswered questions about the novel coronavirus, including the animal sources of infection, transmissibility, and virulence of the virus. This report highlights ongoing clinical trials of vaccines and therapeutics to counter COVID-19 while also focusing on such experiences and advances as made with earlier SARS- and MERS-CoVs, which together could enable efforts to halt this emerging virus infection. We are hopeful that soon this world will be freed from the terrible clutches of COVID-19 and nature will regain its vitality.

\section{Conflicts of Interest}

The authors declare no conflicts of interest regarding the publication of this paper.

\section{References}

[1] Yin, Y. and Wunderink, R. (2017) MERS, SARS and Other Coronaviruses as Causes of Pneumonia. Respirology, 23, 130-137.

[2] Prompetchara, E., Ketloy, C. and Palaga, T. (2020) Immune Responses in COVID19 and Potential Vaccines: Lessons Learned from SARS and MERS Epidemic. Asian Pacific Journal of Allergy and Immunology, 38, 1-9.

[3] Dhoble, C., Saoji, N., Jeswani, J. and Rios, R. (2015) A 45-Year-Old Undiagnosed Cirrhotic Patient with Hepatopulmonary Syndrome as First Presentation: A Case Report. American Journal of Case Reports, 16, 751-755.

[4] (2020) Pneumonia of Unknown Cause-China. World Health Organization. https://www.who.int/csr/don/05-january-2020-pneumonia-of-unkown-cause-china len/.

[5] (2020) Archived: WHO Timeline-COVID-19. Who.Int. https://www.who.int/news-room/detail/27-04-2020-who-timeline---covid-19.

[6] (2020) WHO Announces COVID-19 Outbreak a Pandemic. Euro.Who.Int. https://www.euro.who.int/en/health-topics/health-emergencies/coronavirus-covid19/news/news/2020/3/who-announces-covid-19-outbreak-a-pandemic.

[7] Dhama, K., Sharun, K., Tiwari, R., Dadar, M., Malik, Y., Singh, K. and Chaicumpa, W. (2020) COVID-19, an Emerging Coronavirus Infection: Advances and Prospects in Designing and Developing Vaccines, Immunotherapeutics, and Therapeutics. Human Vaccines \& Immunotherapeutics, 16, 1232-1238. https://doi.org/10.1080/21645515.2020.1735227

[8] Tambyah, P. (2016) Zika, MERS, Ebola, SARS and H1N1: Local and Global Responses to Viral Threats. International Journal of Infectious Diseases, 45, 63. https://doi.org/10.1016/j.ijid.2016.02.182

[9] Lu, H. (2020) Drug Treatment Options for the 2019-New Coronavirus (2019-nCOV). BioScience Trends, 14, 69-71. https://doi.org/10.5582/bst.2020.01020

[10] Sheahan, T., Sims, A., Leist, S., Schäfer, A., Won, J., Brown, A., Montgomery, S., Hogg, A., Babusis, D., Clarke, M., Spahn, J., Bauer, L., Sellers, S., Porter, D., Feng, J., Cihlar, T., Jordan, R., Denison, M. and Baric, R. (2020) Comparative Therapeutic 
Efficacy of Remdesivir and Combination Lopinavir, Ritonavir, and Interferon Beta Against MERS-Cov. Nature Communications, 11, Article No 222. https://doi.org/10.1038/s41467-019-13940-6

[11] Wilder-Smith, A. and Freedman, D. (2020) Isolation, Quarantine, Social Distancing and Community Containment: Pivotal Role for Old-Style Public Health Measures in the Novel Coronavirus (2019-nCoV) Outbreak. Journal of Travel Medicine, 27. https://doi.org/10.1093/jtm/taaa020

[12] Kannan, S., Subbaram, K., Ali, S. and Kannan, H. (2020) Molecular Characterization and Amino Acid Homology of Nucleocapsid (N) Protein in SARS-CoV-1, SARS-CoV-2, MERS-CoV, And Bat Coronavirus. Journal of Pure and Applied Microbiology, 14, 757-763. https://doi.org/10.22207/JPAM.14.SPL1.13

[13] (2020) Coronavirus Update (Live): 29,464,002 Cases and 933,121 Deaths from COVID-19 Virus Pandemic-Worldometer. Worldometers.Info.

https://www.worldometers.info/coronavirus/.

[14] Parry, J. (2003) WHO Warns That Death Rate from SARS Could Reach 10\%. BMJ, 326, 999. https://doi.org/10.1136/bmj.326.7397.999/a

[15] Yao, Z., Zheng, Z., Wu, K. and Junhua, Z. (2020) Immune Environment Modulation in Pneumonia Patients Caused by Coronavirus: SARS-CoV, MERS-CoV and SARS-CoV-2. Aging, 12, 7639-7651. https://doi.org/10.18632/aging.103101

[16] Ahn, D., Shin, H., Kim, M., Lee, S., Kim, H., Myoung, J., Kim, B. and Kim, S. (2020) Current Status Of Epidemiology, Diagnosis, Therapeutics, and Vaccines for Novel Coronavirus Disease 2019 (COVID-19). Journal of Microbiology and Biotechnology, 30, 313-324. https://doi.org/10.4014/jmb.2003.03011

[17] Xie, M. and Chen, Q. (2020) Insight into 2019 Novel Coronavirus-An Updated Interim Review and Lessons from SARS-CoV and MERS-CoV. International Journal of Infectious Diseases, 94, 119-124. https://doi.org/10.1016/j.ijid.2020.03.071

[18] Andersen, K., Rambaut, A., Lipkin, W., Holmes, E. and Garry, R. (2020) The Proximal Origin of SARS-CoV-2. Nature Medicine, 26, 450-452.

https://doi.org/10.1038/s41591-020-0820-9

[19] Huang, C., Wang, Y., Li, X., Ren, L., Zhao, J., Hu, Y., Zhang, L., Fan, G., Xu, J., Gu, X., Cheng, Z., Yu, T., Xia, J., Wei, Y., Wu, W., Xie, X., Yin, W., Li, H., Liu, M., Xiao, Y., Gao, H., Guo, L., Xie, J., Wang, G., Jiang, R., Gao, Z., Jin, Q., Wang, J. and Cao, B. (2020) Clinical Features of Patients Infected with 2019 Novel Coronavirus in Wuhan, China. The Lancet, 395, 497-506. https://doi.org/10.1016/S0140-6736(20)30183-5

[20] Chen, N., Zhou, M., Dong, X., Qu, J., Gong, F., Han, Y., Qiu, Y., Wang, J., Liu, Y., Wei, Y., Xia, J., Yu, T., Zhang, X. and Zhang, L. (2020) Epidemiological and Clinical Characteristics of 99 Cases of 2019 Novel Coronavirus Pneumonia in Wuhan, China: A Descriptive Study. The Lancet, 395, 507-513. https://doi.org/10.1016/S0140-6736(20)30211-7

[21] Wang, D., Hu, B., Hu, C., Zhu, F., Liu, X., Zhang, J., Wang, B., Xiang, H., Cheng, Z., Xiong, Y., Zhao, Y., Li, Y., Wang, X. and Peng, Z. (2020) Clinical Characteristics of 138 Hospitalized Patients With 2019 Novel Coronavirus-Infected Pneumonia in Wuhan, China. JAMA, 323, 1061.

[22] Zhang, J., Dong, X., Cao, Y., Yuan, Y., Yang, Y., Yan, Y., Akdis, C. and Gao, Y. (2020) Clinical Characteristics of 140 Patients Infected with SARS-CoV-2 in Wuhan, China. Allergy, 75, 1730-1741. https://doi.org/10.1111/all.14238

[23] Guan, W., Ni, Z., Hu, Y., Liang, W., Ou, C., He, J., Liu, L., Shan, H., Lei, C., Hui, D., Du, B., Li, L., Zeng, G., Yuen, K., Chen, R., Tang, C., Wang, T., Chen, P., Xiang, J., 
Li, S., Wang, J., Liang, Z., Peng, Y., Wei, L., Liu, Y., Hu, Y., Peng, P., Wang, J., Liu, J., Chen, Z., Li, G., Zheng, Z., Qiu, S., Luo, J., Ye, C., Zhu, S. and Zhong, N. (2020) Clinical Characteristics of Coronavirus Disease 2019 in China. New England Journal of Medicine, 382, 1708-1720. https://doi.org/10.1056/NEJMoa2002032

[24] de Wit, E., van Doremalen, N., Falzarano, D. and Munster, V. (2016) SARS And MERS: Recent Insights Into Emerging Coronaviruses. Nature Reviews Microbiology, 14, 523-534. https://doi.org/10.1038/nrmicro.2016.81

[25] Memish, Z., Perlman, S., Van Kerkhove, M. and Zumla, A. (2020) Middle East Respiratory Syndrome. The Lancet, 395, 1063-1077. https://doi.org/10.1016/S0140-6736(19)33221-0

[26] Holshue, M., DeBolt, C., Lindquist, S., Lofy, K., Wiesman, J., Bruce, H., Spitters, C., Ericson, K., Wilkerson, S., Tural, A., Diaz, G., Cohn, A., Fox, L., Patel, A., Gerber, S., Kim, L., Tong, S., Lu, X., Lindstrom, S., Pallansch, M., Weldon, W., Biggs, H., Uyeki, T. and Pillai, S. (2020) First Case of 2019 Novel Coronavirus in the United States. New England Journal of Medicine, 382, 929-936. https://doi.org/10.1056/NEJMoa2001191

[27] Li, Y. and Xia, L. (2020) Coronavirus Disease 2019 (COVID-19): Role of Chest CT in Diagnosis and Management. American Journal of Roentgenology, 214, 1280-1286. https://doi.org/10.2214/AJR.20.22954

[28] (2020) Clinical Management of COVID-19. Who.Int. https://www.who.int/publications/i/item/clinical-management-of-severe-acute-resp iratory-infection-when-novel-coronavirus-(ncov)-infection-is-suspected.

[29] Arakawa, M. and Morita, E. (2019) Flavivirus Replication Organelle Biogenesis in the Endoplasmic Reticulum: Comparison with Other Single-Stranded Positive-Sense RNA Viruses. International Journal of Molecular Sciences, 20, 2336. https://doi.org/10.3390/ijms20092336

[30] Liaw, C., Lim, A., Koh, W., Loh, J., Kan, C., Chan, K., Ting, P., Ng, S., Chew, S., Dua, A., Tan, C., Gao, Q., Ho, H., lee, V. and Tan, B. (2012) Epidemiology of the Four Human Coronaviruses 229E, HKU1, NL63 and OC43 Detected over 30 Months in the Singapore Military. International Journal of Infectious Diseases, 16, e135. https://doi.org/10.1016/j.ijid.2012.05.305

[31] Lvov, D. and Alkhovsky, S. (2020) Source of the COVID-19 Pandemic: Ecology and Genetics of Coronaviruses (Betacoronavirus: Coronaviridae) SARS-CoV, SARS-CoV-2 (Subgenus Sarbecovirus), and MERS-CoV (Subgenus Merbecovirus). Problems of Virology, Russian journal, 65, 62-70.

https://doi.org/10.36233/0507-4088-2020-65-2-62-70

[32] Satheshkumar, P., Weisberg, A. and Moss, B. (2013) Vaccinia Virus A19 Protein Participates in the Transformation of Spherical Immature Particles to Barrel-Shaped Infectious Virions. Journal of Virology, 87, 10700-10709.

https://doi.org/10.1128/JVI.01258-13

[33] Li, G., Fan, Y., Lai, Y., Han, T., Li, Z., Zhou, P., Pan, P., Wang, W., Hu, D., Liu, X., Zhang, Q. and $\mathrm{Wu}$, J. (2020) Coronavirus Infections and Immune Responses. Journal of Medical Virology, 92, 424-432. https://doi.org/10.1002/jmv.25685

[34] Struck, A., Axmann, M., Pfefferle, S., Drosten, C. and Meyer, B. (2012) A Hexapeptide of the Receptor-Binding Domain of SARS Corona Virus Spike Protein Blocks Viral Entry into Host Cells Via The Human Receptor ACE2. Antiviral Research, 94, 288-296. https://doi.org/10.1016/j.antiviral.2011.12.012

[35] Chenon, M., Camborde, L., Cheminant, S. and Jupin, I. (2011) A Viral Deubiquitylating Enzyme Targets Viral RNA-Dependent RNA Polymerase and Affects Viral 
Infectivity. The EMBO Journal, 31, 741-753.

https://doi.org/10.1038/emboj.2011.424

[36] Moon, S. and Wilusz, J. (2014) Viral Rnas versus the Cellular RNA Decay Machinery. Microbe Magazine, 9, 105-110. https://doi.org/10.1128/microbe.9.105.1

[37] Othman, H., Bouslama, Z., Brandenburg, J., da Rocha, J., Hamdi, Y., Ghedira, K., Srairi-Abid, N. and Hazelhurst, S. (2020) Interaction of the Spike Protein RBD from SARS-CoV-2 with ACE2: Similarity with SARS-CoV, Hot-Spot Analysis and Effect of the Receptor Polymorphism. Biochemical and Biophysical Research Communications, 527, 702-708. https://doi.org/10.1016/j.bbrc.2020.05.028

[38] Liu, C., Zhou, Q., Li, Y., Garner, L., Watkins, S., Carter, L., Smoot, J., Gregg, A., Daniels, A., Jervey, S. and Albaiu, D. (2020) Research and Development on Therapeutic Agents And Vaccines for COVID-19 and Related Human Coronavirus Diseases. ACS Central Science, 6, 315-331. https://doi.org/10.1021/acscentsci.0c00272

[39] Elshabrawy, H. (2020) SARS-CoV-2: An Update on Potential Antivirals in Light of SARS-CoV Antiviral Drug Discoveries. Vaccines, 8, 335.

https://doi.org/10.3390/vaccines8020335

[40] Iacobucci, G. (2020) Covid-19: UK Pledges to Reintroduce Contact Tracing to Fight Virus. BMJ, 369, m1591. https://doi.org/10.1136/bmj.m1591

[41] (2020) Modes of Transmission of Virus Causing COVID-19: Implications for IPC Precaution Recommendations. Who.Int.

https://www.who.int/news-room/commentaries/detail/modes-of-transmission-of-vi rus-causing-covid-19-implications-for-ipc-precaution-recommendations.

[42] Cai, J., Sun, W., Huang, J., Gamber, M., Wu, J. and He, G. (2020) Indirect Virus Transmission in Cluster of COVID-19 Cases, Wenzhou, China, 2020. Emerging Infectious Diseases, 26, 1343-1345. https://doi.org/10.3201/eid2606.200412

[43] Hormati, A., Shahhamzeh, A., Afifian, M., Khodadust, F. and Ahmadpour, S. (2020) Can COVID-19 Present Unusual GI Symptoms? Journal of Microbiology, Immunology and Infection, 53, 384-385. https://doi.org/10.1016/j.jmii.2020.03.020

[44] Lodder, W. and de Roda Husman, A. (2020) SARS-CoV-2 in Wastewater: Potential Health Risk, But Also Data Source. The Lancet Gastroenterology \& Hepatology, 5, 533-534. https://doi.org/10.1016/S2468-1253(20)30087-X

[45] Murakami, M., Hata, A., Honda, R. and Watanabe, T. (2020) Letter to the Editor: Wastewater-Based Epidemiology Can Overcome Representativeness and Stigma Issues Related to COVID-19. Environmental Science \& Technology, 54, 5311. https://doi.org/10.1021/acs.est.0c02172.

[46] Du, L., He, Y., Zhou, Y., Liu, S., Zheng, B. and Jiang, S. (2009) the Spike Protein of SARS-CoV-A Target for Vaccine and Therapeutic Development. Nature Reviews Microbiology, 7, 226-236. https://doi.org/10.1038/nrmicro2090

[47] Poland, G. (2020) Tortoises, Hares, and Vaccines: A Cautionary Note for SARSCoV-2 Vaccine Development. Vaccine, 38, 4219-4220.

https://doi.org/10.1016/j.vaccine.2020.04.073

[48] Alharbi, N., Padron-Regalado, E., Thompson, C., Kupke, A., Wells, D., Sloan, M., Grehan, K., Temperton, N., Lambe, T., Warimwe, G., Becker, S., Hill, A. and Gilbert, S. (2017) Chadox1 And MVA Based Vaccine Candidates Against MERS-CoV Elicit Neutralising Antibodies and Cellular Immune Responses in Mice. Vaccine, 35, 3780-3788. https://doi.org/10.1016/j.vaccine.2017.05.032

[49] (2020) University Of Oxford Commences Clinical Trial for Vaccine Candidate (Chadox1 Ncov-19) Targeting COVID-19. Trial Site News. 
https://www.trialsitenews.com/university-of-oxford-commences-clinical-trial-for-v accine-candidate-chadox1-ncov-19-targeting-covid-19-2/.

[50] Zhao, Q. and He, Y. (2020) Challenges of Convalescent Plasma Therapy on COVID-19. Journal of Clinical Virology, 127, 104358. https://doi.org/10.1016/j.jcv.2020.104358

[51] (2020) Draft Landscape of COVID-19 Candidate Vaccines. Who.Int. https://www.who.int/publications/m/item/draft-landscape-of-covid-19-candidate-v accines.

[52] Jiang, X., Rayner, S. and Luo, M. (2020) Does SARS-Cov-2 Has A Longer Incubation Period Than SARS And MERS? Journal of Medical Virology, 92, 476-478.

[53] Uddin, M., Mustafa, F., Rizvi, T., Loney, T., Al Suwaidi, H., Al-Marzouqi, A., Kamal Eldin, A., Alsabeeha, N., Adrian, T., Stefanini, C., Nowotny, N., Alsheikh-Ali, A. and Senok, A. (2020) SARS-CoV-2/COVID-19: Viral Genomics, Epidemiology, Vaccines, and Therapeutic Interventions. Viruses, 12, 526. https://doi.org/10.3390/v12050526

[54] Zhou, J., Wang, W., Zhong, Q., Hou, W., Yang, Z., Xiao, S., Zhu, R., Tang, Z., Wang, Y., Xian, Q., Tang, H. and Wen, L. (2005) Immunogenicity, Safety, and Protective Efficacy of an Inactivated SARS-Associated Coronavirus Vaccine in Rhesus Monkeys. Vaccine, 23, 3202-3209. https://doi.org/10.1016/j.vaccine.2004.11.075

[55] Stower, H. (2020) Lopinavir-Ritonavir in Severe COVID-19. Nature Medicine, 26, 465. https://doi.org/10.1038/s41591-020-0849-9

[56] Agostini, M., Andres, E., Sims, A., Graham, R., Sheahan, T., Lu, X., Smith, E., Case, J., Feng, J., Jordan, R., Ray, A., Cihlar, T., Siegel, D., Mackman, R., Clarke, M., Baric, R. and Denison, M. (2018) Coronavirus Susceptibility to the Antiviral Remdesivir (GS-5734) Is Mediated by the Viral Polymerase and the Proofreading Exoribonuclease. mBio, 9, e00221-18. https://doi.org/10.1128/mBio.00221-18

[57] Cao, B., Wang, Y., Wen, D., Liu, W., Wang, J., Fan, G., Ruan, L., Song, B., Cai, Y., Wei, M., Li, X., Xia, J., Chen, N., Xiang, J., Yu, T., Bai, T., Xie, X., Zhang, L., Li, C., Yuan, Y., Chen, H., Li, H., Huang, H., Tu, S., Gong, F., Liu, Y., Wei, Y., Dong, C., Zhou, F., Gu, X., Xu, J., Liu, Z., Zhang, Y., Li, H., Shang, L., Wang, K., Li, K., Zhou, X., Dong, X., Qu, Z., Lu, S., Hu, X., Ruan, S., Luo, S., Wu, J., Peng, L., Cheng, F., Pan, L., Zou, J., Jia, C., Wang, J., Liu, X., Wang, S., Wu, X., Ge, Q., He, J., Zhan, H., Qiu, F., Guo, L., Huang, C., Jaki, T., Hayden, F., Horby, P., Zhang, D. and Wang, C. (2020) A Trial of Lopinavir-Ritonavir in Adults Hospitalized with Severe Covid-19. New England Journal of Medicine, 382, 1787-1799. https://doi.org/10.1056/NEJMoa2001282

[58] Yanai, H. (2020) Favipiravir: A Possible Pharmaceutical Treatment for COVID-19. Journal of Endocrinology and Metabolism, 10, 33-34. https://doi.org/10.14740/jem645

[59] Ito, K., Ohmagari, N., Mikami, A. and Sugiura, W. (2020) Major Ongoing Clinical Trials for COVID-19 Treatment and Studies Currently Being Conducted or Scheduled in Japan. Global Health \& Medicine, 2, 96-101.

[60] Kmietowicz, Z. (2020) Covid-19: Selected NHS Patients Will Be Treated with Remdesivir. BMJ, 369, m2097. https://doi.org/10.1136/bmj.m2097

[61] (2020) 15 Drugs Being Tested to Treat COVID-19 and How They Would Work. Nature.Com. https://www.nature.com/articles/d41591-020-00019-9.

[62] Caly, L., Druce, J., Catton, M., Jans, D. and Wagstaff, K. (2020) The FDA-Approved Drug Ivermectin Inhibits the Replication of SARS-Cov-2 in Vitro. Antiviral Research, 178, 104787. https://doi.org/10.1016/j.antiviral.2020.104787 